\title{
Mary Versus Eve: Paternal Uncertainty and the Christian View of Women
}

\section{Vladimir Tumanov}

\section{Neophilologus}

An International Journal of Modern and Mediaeval Language and Literature

\section{ISSN 0028-2677}

Volume 95

Number 4

Neophilologus (2011) 95:507-521

DOI 10.1007/s11061-011-9253-5

\section{Neophilologus}

An international journal

of modern and mediaeval language

and literature

\section{Volume 95 (2011)}




\title{
Mary Versus Eve: Paternal Uncertainty and the Christian View of Women ${ }^{1}$
}

\author{
By Vladimir Tumanov \\ Western University
}

\section{Abstract}

The Virgin Mary and Eve constitute two opposite sexual poles in the way Christian discourse has approached women since the time of the church fathers. This stems from a predicament faced by the human male throughout hominid evolution, namely, paternal uncertainty. Because the male is potentially always at risk of unwittingly raising the offspring of another male, two (often complementary) male sexual strategies have evolved to counter this genetic threat: mate guarding and promiscuity. The Virgin Mary is the mythological expression of the mate guarding strategy. Mary is an eternal virgin, symbolically allaying all fear of paternal uncertainty. Mary makes it possible for the male psyche to have its reproductive cake and eat it too: she gives birth (so reproduction takes place) and yet requires no mate guarding effort or jealousy. Eve, the inventor of female sexuality, is repeatedly viewed by the church fathers, e.g., Augustine and Origen, as Mary's opposite. Thus, Eve becomes the embodiment of the whore: both attractive in the context of the promiscuity strategy and repulsive in terms of paternal uncertainty: "Death by Eve, life by Mary" (St. Jerome). The Mary-Eve dichotomy has given a conceptual basis to what is known in psychology as the Madonna-Whore dichotomy: the tendency to categorize women in terms of two polar opposites. This paper will explore the way mythology reflects biology, i.e., human psychological traits that have evolved over millennia.

Keywords Evolutionary psychology _ History of religion _ Paternal uncertainty Misogyny _ Virgin Mary _ Eve _ Church fathers _ Madonna-Whore Dichotomy _ Approach-avoidance conflict

\footnotetext{
${ }^{1}$ Published article here: http://www.springerlink.com/content/15p628061270vx41/
} 


\section{Introduction}

Much of the discourse in the relatively new field of Evolutionary Psychology is based on a simple premise, namely, that the reproductive strategies, pitfalls and fears of human males and females are different because the female always knows that her genes are being passed on into the next generation while the male can never be absolutely sure. As Donald Symons (1979) puts it, extra-pair mating is a far greater threat to males than to females because "a man never can be certain of paternity, [i.e.], a cuckold risks investing in the offspring of [...] a reproductive competitor; as a woman is always certain of maternity $[\ldots]$, a wife may risk little if her husband engages in extramarital sex" (241). In other words, while the female in the prehistoric or ancestral environment risked at most being abandoned by her mate (which could have reduced the survival prospects of existing offspring but did not necessary spell its doom), the cuckolded male risked genetic extinction pure and simple. Therefore, male feelings and associated behaviors aimed at increasing the likelihood of raising one's own offspring were selected for in the evolution of the hominid species while the opposite was not. One such feeling is male anxiety stemming from paternal uncertainty. Since mythology is the symbolic manifestation of our two key biological concerns - survival and reproduction - the question that I would like to explore is how paternal uncertainty manifests itself in Christian discourse. Namely, I wish to consider Eve and the Virgin Mary as the two key female figures representative of anxiety associated with paternal uncertainty. What do these characters say about the male psyche given that the texts from which we know them are the products of male creative and religious drives?

\section{Jealous Man}

The male's evolutionary reaction to the above-mentioned state of perpetual paternal uncertainty consists of two strategies: a) promiscuity which allows the male to maximize his chances of reproduction by seeking as many partners as possible (cf. Brown and Amatea 200: 293; Riddley, 2003: 179) 
and b) mate guarding whereby the male seeks to reduce the chances of extrapair mating on the part of the female. Mate guarding expresses itself in "veiling, chaperoning, purdah, and the literal incarceration of women [which] are common social institutions of patrilineal societies [...] The repeated convergent invention of claustration practices around the world and the confining and controlling behavior of men even where it is frowned upon reflect the workings of a sexually proprietary male psychology" (Wilson and Daly 1992: 301). As for the feelings which have evolved to provoke the behavior of mate guarding, jealousy is the key emotional engine.

David Buss talks of the jealousy bias that is hard-wired into the male psyche by thousands of years of selection pressure: "In the context of jealousy and mate guarding, it is reasonable to hypothesize that it would be more costly for a person to err by failing to detect a partner's infidelity than to erroneously infer an infidelity that has not occurred. A condition that likely facilitated the evolution of a 'jealousy bias' that functioned to over-infer infidelity is the great uncertainty that surrounds the detection of infidelity" (2002: 27; cf. Buss, 2000: 7). Buss (2002) refers to this propensity as the Othello Syndrome and cites numerous cross-cultural studies which make it clear that this is not merely a culturally-determined phenomenon - contrary to claims made by early twentieth-century anthropologists like Margaret Mead (Riddley, 1996: 256-7). Furthermore, that the jealousy bias associated with paternal uncertainty is not just a figment of the male imagination is corroborated by blood sample studies of various population groups in different parts of the world. The conclusion is that typically up to 10 per cent of children are the result of "paternal discrepancy" in many societies, i.e., they are not the progeny of men who assume to be their fathers (Mollon, 2002: 121; cf. Bellis et al., 2005: 750 and Baker, 2006: 146). 


\section{Jealous God}

In the Old Testament the jealousy bias is expressed by the legal meaning of the Decalogue's seventh commandment: "You shall not commit adultery" (Exodus 20:14). This interdiction pertains to women's behavior, i.e., adultery is only extra-pair mating by a woman since it increases paternal uncertainty. A married man who has sex with another man's wife is not seen as harming his own wife, but rather as undermining the genetic survival of the adulteress' husband. So a man can technically commit adultery to be sure, but it is still about the effect of this act on another man's reproductive potential (cf. RankeHeinemann, 1990: 34). This biblical legal link with paternal uncertainty manifested itself for centuries and until very recent times, e.g., the Napoleonic code viewed adultery as a female crime (R. Miller, 2007: 100). Similarly, according to article 324 in the French Penal Code of 1810, a husband who caught his wife committing adultery could kill her with impunity (Holmberg, 2007). Even remarriage has been associated with the male anxiety-ridden logic characterizing the seventh commandment; thus, the Spanish Synod of Elvira and the Synod of Arles in the 4th century CE allowed men to remarry but ruled that women who remarry should be excommunicated (Ranke-Heinemann, 1990: 36).

The other major manifestation of the jealousy bias in the Old Testament - and one clearly related to the seventh commandment - is the projection of paternal uncertainty by the male authors of these texts onto the male deity. From the very beginning of his association with the Israelites after the exodus from Egypt, Yahweh makes it plain that he is beset by the Othello Syndrome: "You shall have no other gods before me [...] for I the Lord your God am a jealous God" (Exodus 20:3). In fact, the relationship between the deity and his chosen people is clearly modeled on marriage: "The figure of Israel as YHWH's wife derives from the cardinal commandment that Israel worship YHWH alone. To that demand of exclusive fidelity, the obligation of a wife to her husband offered a parallel" (Davidson, 2009: 337). Thus, in the Song of Songs we find a dialogue between two lovers who are in the heat of passion: 
"Your neck is like the tower of David, built in courses; on it hang a thousand bucklers, all of them shields of warriors. Your two breasts are like two fawns, twins of a gazelle, that feed among the lilies" (4:4-5).

The most common interpretation of the Song of Songs is as a metaphor for the relationship between the god of Israel and his people, i.e., the form is that of marriage and marital fidelity. Because Israel's path toward monotheism is a long and difficult one, involving frequent returns to pagan practices (in biological terms: extra-pair mating), various parts of the Old Testament indicate that god's original claim of jealousy from Exodus is not just an empty threat. The passionate lover from the Song of Songs turns out to be a jealous paramour any time the Israelites consider other gods (e.g., Joshua 24:19; Nahum 1:2), and he punishes his "consort" for breaking the covenant of exclusive marital faithfulness: "I will judge you as women who commit adultery and shed blood are judged, and bring blood upon you in wrath and jealousy" (Ezek 16:38; also cf. Ezekiel 42 and 23:25). The same marital imagery is inherited by Christianity with the New Israel (the early Christians) acting out the role of the genetically dangerous female consort. Thus, we have the following passage from Paul: "I feel a divine jealousy for you, for I betrothed you to Christ to present you as a pure bride to her one husband. But I am afraid that as the serpent deceived Eve by his cunning, your thoughts will be led astray from a sincere and pure devotion to Christ" (2 Corinthians 11:2-3). The connection of paternal uncertainty with Eve is of paramount importance to the argument in this article, and it will be dealt with below. For now, however, we see that whether god is Yahweh or his son, the harried male psyche responsible for scripture cannot shake the biological fears inherent in being a man.

The projection of paternal uncertainty in the form of jealousy onto the Israelite god in the Old Testament and onto Jesus in the New Testament can certainty be viewed as a reflection of an exaggerated anxiety. However, this fear is by no means without evolutionary foundation from the female perspective: "A woman's ideal mating strategy involves securing a mate who 
can not only provide good genes, but one who is also capable and willing to invest in offspring. [...] Women may have evolved the willingness to secure a mate with material resources and emotional investment, while at the same time obtaining a high-quality genetic contribution from another partner" (Lalumière \& Suschinsky, 2007: 359). Or, to put this in the frivolous terms of the musical Chicago:

$$
\begin{aligned}
& \text { You can live the life you're living. } \\
& \text { You can live the life you like. } \\
& \text { You can even marry Harry, } \\
& \text { But mess around with Mike. (Ebb) }
\end{aligned}
$$

Like any Harry who is dependent on a woman for reproduction and yet painfully aware that he might be raising Mike's children, the deity finds himself in a bind. Without his consort Israel, the Old Testament god cannot continue to exist, and yet, as the biblical prophets never tire of pointing out, Israel is hardly a paragon of wifely fidelity as she repeatedly bows down to Ashera and other Canaanite deities (e.g., 2 Kings 21:7). In psychological terms, this is what Kurt Lewin calls the approach-avoidance conflict, i.e., the anxiety experienced by someone who is "caught by being attracted, and repelled by, the same goal or activity. Attraction keeps the person in the situation, but its negative aspects cause turmoil and distress (Coon and Mitterer, 2010: 439; cf. Elliot and Covington, 2001: 85).

For the traumatized male psyche, the attempted resolution of Lewin's approach-avoidance conflict in this connection can take various forms. For example, in the Old and New Testament's endless "begats" we find the implicit denial of female involvement in the reproductive process, i.e., men appear to generate progeny on their own as in the following well-known passage from the King James Bible: "Abraham begat Isaac; and Isaac begat Jacob; and Jacob begat Judas and his brethren" (Mattew 1:2). At least at the level of language, the male eliminates paternal uncertainty - in a manner of speaking. Then there is of course the above-mentioned violent jealousy of the Hebrew god who punishes Israel's adultery by having the Jewish state destroyed at the 
hands of the Babylonian king Nebuchadnezzar II in 587 BCE and sending the entire people into Babylonian captivity. However, this solution is faulty because in trying to reduce the avoidance side of the conflict, the deity endangers the whole enterprise, namely, in Babylonian captivity Israel is in danger of vanishing as a group of Yahweh worshippers and thereby dooming the jealous god to theological extinction. In fact, judging by the Babylonized names of those who return to Palestine from Babylon in the book of Nehamiah (e.g., Zerubbabel) and the fact that they have married Babylonian women (Ezra $10: 1-44)$, the near demise of Yahweh appears as a distinct possibility.

\section{No Sex}

Given that denial and punishment offer only a partially satisfying solution to the approach-avoidance conflict within the male psyche, another idea is the attempt to "seal the womb," so to speak, by emphasizing virginity and condemning sexuality as a whole. This notion does not gather true momentum until the advent of Christianity, but in pre-Christian societies we do observe certain precursors. Thus, sexuality is viewed with suspicion and even condemnation by Plato, Aristotle and Hippocrates, as well as the Stoic philosophers, Pliny the Elder, the Gnostics and the Essenes (Ranke-Heinemann, 1990: 10-17). However, in the pagan world and in biblical Judaism the rejection of sexuality and the praise of virginity did not constitute a major ideological movement. The Christian church fathers, on the other hand, turned this idea into an obsession which became so pervasive over the centuries after Christ that one can view it as the virtual hallmark of the entire religion. Justin Martyr, Clement of Alexandria, Origen and others adopted a radical stance in this connection, condemning sexual contact with women as the source of all evil (Ranke-Heinemann, 1990: 46-52). However, the vilification of sexual pleasure reached a truly hysterical pitch in the writings of the most influential church father, St. Augustine, who turned the quest for asexuality into an institution. As Ute Ranke-Heinemann (1990) points out, St. Augustine viewed original sin as something passed on from generation to generation through the 
sexual act and therefore pleaded for the "so-called Josephite marriage, that is, total continence in marriage, as reflected in many lives of saints. [...] In Augustine's eyes virginity is morally higher than marriage with sex" (97). Of course all this was the ideological groundwork which would eventually lead to institutionalized celibacy in the Catholic Church and its inevitable corollary vitriolic misogyny.

The problem with this discourse is that it represents yet again only a partial solution of the approach-avoidance conflict. Indeed, without sex there is no paternal uncertainty so the Christian obsession with virginity appears as an ideological pain-killer. However, as in the case of real pain-killers, mythology does not offer a real cure for biology, i.e., the reproductive impulse (the approach side of Lewin's conflict scheme) still plagues the male psyche. Mythological discourse does attempt to offer a shaky solution. Thus, Gregory of Nyssa talks about reproduction in the prelapsarian state where "life was like that of the angels, who multiply without marriage and sexual reproduction" an idea echoed by John Chysostom in a text aptly entitled De virginitatae (Ranke-Heinemann, 1990: 52-55). However, biological men do not exist in the prelapsarian state and have nothing to do with the angels. And so, Christian discourse came up with an ingenious attempt to overcome biology through mythology, namely, by splitting up the female into two distinct figures: Eve (along with her heirs) and the Virgin Mary. Correspondingly, the approachavoidance conflict is also "rent in twain" and presumably eliminated since sexual Eve (avoidance) and asexual Mary (approach) do not intersect. Or, to put this in terms of Lewin's conflict resolution theory, "it is only when the [approach and avoidance] gradients intersect that one has a true approachavoidance conflict" (Gerard and Orive, 1987, 178).

\section{Eve the Whore}

The attempt to avoid this intersection appears quite early in Christian ideology, and, as Monika Wohlrab-Sahr and Julika Rosenstock (2000) put it, "of particular significance is the symbolic opposition of two female ideal types in 
Catholicism: Eve vs. the Virgin Mary. As a 'daughter of Eve,' woman is viewed as lascivious and largely unable to control her weaknesses [...]. This female force brings Original Sin and sexuality in equal measure into the world, and it is counterbalanced by Mary who simultaneously stands for motherhood and purity" (292 - my translation). Although the combination of motherhood and purity appears as a logical contradiction, this becomes a symbol of the quest to vanquish paternal uncertainty by means of mythology. Again and again, the church fathers juxtapose the two female figures in terms of failed and successful virginity respectively. Thus, Tertulian writes: "For into Eve, as yet a virgin, had crept the word which was the framer of death. Equally into a virgin was to be introduced the Word of God which was the builder-up of life; that, what by that sex had gone into perdition, by the same sex might be brought back to salvation." St. Ireineus makes a similar opposition: "With a fitness, Mary the Virgin is found obedient [...] but Eve was disobedient; for she obeyed not, while she was yet a virgin" (Boyce, 2001: 210). And St. Jerome sums up the situation succinctly in his 22nd Epistle: "Death by Eve, life by Mary" (Boyce, 2001: 218).

Eve is given so much negative weight because, as the inventor of sexuality, she epitomizes paternal uncertainty. It is through her action of biting the fruit of knowledge (Genesis 3:6) that sexual activity becomes a part of human existence: the primordial pair first feels shame at their nakedness (Genesis 3:7) and then engages in the sexual act (Genesis 4:1). We should note the sexual connotation of "knowledge," namely, the fruit of knowledge tasted by Eve on the one hand and the fact that the sexual act between Adam and Eve is also referred to by the Hebrew verb "to know" (Westermann, 1994: 243). In fact, because she is the first one to disobey the divine interdiction, Eve represents not just female sexuality but specifically female sexual choice the real source of masculine anxiety. The female under complete male control is an ideal toward which the male psyche strives because only such a sexual monopoly can alleviate paternal uncertainty. However, the unsettling events of Genesis 2-3 illustrate in symbolic terms that this control is as impossible as 
Gregory of Nyssa's and John Chysostom's above-cited idea of asexual reproduction.

In fact, given the choice of animal for the seduction of Eve in Genesis 3, the obvious phallic connotations of the serpent's body have been inferred by many commentators from rabbinical sources all the way to Sigmund Freud. This has produced the well-known subtext of Adam's cuckolding by Eve (cf. Garber, 2003: 45 and Morrison, 2009: 176). And so Tertullian (Roberts and Donaldson, 1885-1896) expresses the masculine frustration with inevitable biological reality by extrapolating from Eve to all womanhood: "Do you not know that you are each an Eve?" (14). The medieval proponents of this position include Albert the Great (the teacher of St. Thomas Aquinas) who has the following to say about Eve's heirs: "When a woman has relations with a man, she would like, as much as possible, to be lying with another man at the same time." Albert then goes on to use imagery evocative of the Eden story, arguing that "one must be on guard with every woman, as if she were a poisonous snake and the horned devil" (Ranke-Heinemann, 1990: 178). This rhetoric suggests that paternal uncertainty can never be eliminated as long as female sexuality exists. The logic here evokes the notion of sperm competition from Evolutionary Psychology, namely, that ancestral human females evolved to occasionally collect the sperm of several males within a short period of time in order to let the fittest sperm win the race to reach the egg (Baker, 2006: 46; cf. Riddley, 2003: 219-221). The difference between Evolutionary Psychology and medieval ideology is that the latter views as a universal behavioral norm that which the former sees as only one among several female reproductive strategies.

It is this obsessive concentration on a single aspect of female sexuality (mediated by fervent Mariological discourse) that eventually led to the witch hunts of the late Middle Ages and beyond (cf. Schaber, 1987: 13). Tens of thousands of women were tortured and/or killed in Europe on charges of witchcraft whereby a key accusation was sexual misconduct, i.e., female sexuality outside of masculine control (cf. Hays, 1964: 148). Thus, according 
to the Compendium Maleficarum by Francesco Maria Guazzo (1608), the witches' Sabbath involved fornication with the devil and orgies (Hays, 1964: 156). Important for our argument is the fact that the connection of witches with Eve was always present, e.g., in 17th century New England "Eve was the main symbol of woman-as-evil in the Puritan culture. She was, in many ways, the archetypal witch" (Karlsen, 1987: 177). Likewise, the famous Malleus Maleficarum of 1484 (issued by the monks Jacob Sprenger and Heinrich Krämer) links witches with Eve: "All witchcraft comes from carnal lust which in women is insatiable. For although the devil tempted Eve, yet Eve seduced Adam" (Hays, 1964: 153). That all this stems from the anxiety of paternal uncertainty is made evident by Christina Larner who points out the following with respect to the witch hunts in Scotland: "Women are feared as a source of disorder in patriarchal society. [...] It is only by exhibiting total control over the lives and bodies of their women that men can know that their children are their own" (Larner, 1981: 93). Thus, Eve and her heirs come to symbolize the kind of female sexuality that is perceived as a genetic threat to the male.

\section{Mary the Ultimate}

So much for the avoidance part of Lewin's conflict. The approach side is, as argued above, symbolized by the Virgin Mary: "When [...] Mary had been engaged to Joseph, but before they lived together, she was found to be with child from the Holy Spirit" (Matthew 1:18). Because Mary remains a virgin when she conceives Jesus in the Gospels of Luke and Matthew, she allows the male psyche to have its reproductive cake and eat it too. Finally, here is a female figure who makes it possible to resolve the approach-avoidance conflict by bearing offspring without the ability to cuckold the male - a fact beyond any doubt because its veracity is guaranteed by the highest (divine) authority: "An angel of the Lord appeared to [Joseph] in a dream and said, 'Joseph, son of David, do not be afraid to take Mary as your wife, for the child conceived in her is from the Holy Spirit' " (Matthew 1:20). The "Josephite marriage," so extolled by St. Augustine (see above), appears to work because Joseph and 
god are not from the same species. If we approach this as the mythological (symbolic) manifestation of the male psyche, an important biological notion can be helpful, namely, that genetic competition happens primarily within a given species (Baumeister and Bushman, 2008: 34). In other words, the human male has evolved to experience anxiety associated with paternal uncertainty in connection to other men: "Among sexually reproducing organisms, every conspecific is to a greater or lesser extent one's reproductive competitor" (Symons, 1979: 229). Since god is not a conspecific, Joseph has not been cuckolded and yet he has a son!

The above, however, has to do with only one aspect of Mary's virginity: that of a mate. As Christian tradition evolved and went beyond the biblical texts, Mary turned out to be a virgin and a mother as well. Eve demonstrates that all women start out as virgins, but that is no guarantee of immunity from future cuckoldry for men. Thus, in the eyes of Tertulian "a virgin ceases to be a virgin from the time it becomes possible for her not to be one" while John Chrysostom says that "even when virginal women are separated from men by a wall, they are still suspect" (Bloch, 1991: 101). And so, in order to give paternal uncertainty its symbolic coup de grace, the church fathers needed a super virgin - one whose virginity can be certified as permanent. Hence, the doctrine of Mary's virginity beyond the moment of conception. As the Catholic catechism of 499 states, Mary remains a virgin for the rest of her life and even in the process of bearing Jesus, i.e., her hymen is not broken. The result is that the mention of Jesus' brothers and sisters in the New Testament is not to be taken literally but rather as references to close relatives or cousins. This doctrine is picked up by the reformers of the 16th century, as well as the Greek Orthodox Church (Lüdemann, 1998: 12-14; cf. Ranke-Heinemann, 1990: 31 and 91).

The difference between Mary and Eve is particularly sharp in connection with the punishment meted out to Eve for her transgression in Eden: "I will greatly increase your pangs in childbearing; in pain you shall bring forth children" (Genesis 3:16). The bearing of children is the obvious counterpart of 
conception - the two sides of the non-virginal state - both of which have to do with the "unsealing" of the birth canal. However, given that Mary never loses her virginal state, Jesus comes out of Mary "the way spirits pass through bodies without resistance" (Ranke-Heinemann, 1990: 342). Therefore, because Eve's sentence of painful childbirth does not apply to Mary, the latter can now occupy Eve's prelapsarian position, which is why Justin Martyr sees Mary as the second Eve (Ashe, 1988: 124). Since "the Fall can be related thematically to a loss of virginity [and given] how powerful is the nostalgia for a return to a time before the Fall" (Bloch, 1991: 98-9), Mary's painless virginal childbirth undoes the Fall and symbolically gives Adam (as the embodiment of manhood in general) the peace of mind that he lost in Genesis 3. By becoming a prelapsarian Eve, Mary brings Adam back to his own prelapsarian position since it is only through Eve's transgression (as the Catholic Church repeatedly argued from Augustine on) that Adam fell to begin with. ${ }^{2}$ In this manner, Mary uncuckolds not only Joseph but Adam as well (recall the subtext of Adam's cuckolding). Finally, the symbolic model for calming the genetic anxiety of the male psyche appears to work... or does it?

\section{Mary the Scandalous}

In order to deal with this question, let us look at the relevant passages in the New Testament and subsequent reactions to this text. Consider Joseph's initial response to the news of Mary's pregnancy in Matthew: he views the situation as a simple case of premarital sex between his betrothed and some male rival. Joseph does not vituperate and express his indignation publically. Neither does he choose to follow Deuteronomy which prescribes the following course of action for a man in Joseph's position: "If there is a young woman, a virgin already engaged to be married, and a man meets her in the town and

${ }^{2}$ One of Tertullian's most famous and quoted passages goes like this: "You are the Devil's gateway. You are the unsealer of the forbidden tree. You are the first deserter of the divine law. You are she who persuaded him whom the devil was not valiant enough to attack. You destroyed so easily God's image, man. On account of your desert — that is death — even the Son of God had to die" (14). 
lies with her, you shall bring both of them to the gate of that town and stone them to death (22:23). Instead, Joseph adopts a more moderate solution: "Her husband Joseph, being a righteous man and unwilling to expose her to public disgrace, planned to dismiss her quietly" (Matthew 1:19). The point is that Joseph's decision to dismiss the "blemished" bride makes perfect biological (rather than mythological) sense: he does not wish to spell his own genetic oblivion by raising the child of a conspecific competitor. Joseph's behavior fits into the age-old mould of paternal uncertainty and indicates that his mind works like that of any other male. As Richard Dawkins (2006) points out, the idea behind the extended engagement period is to "wait and see whether [the female] is harboring any little step-children in her womb, and desert her if so" (147-8). However, all this changes when mythology trumps biology, i.e., once Joseph hears and accepts the supernatural explanation. While the biological Joseph would be shutting the door to the future for his (genetic) being by agreeing to raise Mary's offspring instead of his own, the mythological Joseph gains access to eternal existence since the continuity of selfhood in Christianity is ensured at the spiritual (rather than the genetic) level - through the salvation of the soul. And so the groom appears appeased, marries Mary and lives happily ever after. The End? Not quite...

Hints of the scandal behind Jesus' conception are visible already in the New Testament. Jesus is rejected in his hometown as follows: "Is not this the craftsman, the son of Mary and brother of James and Joses and Judas and Simon, and not his sisters with us? And they took offence at him" (Mark 6:3). The phrase "son of Mary" should raise eyebrows since according to Jewish tradition, patrilineal descent was the norm: recall the above-mentioned begats where "Abraham begat Isaac" etc. Therefore, "son of Mary" would imply that Jesus is being taunted by his detractors for being a bastard, i.e., his father is unknown. As Gerd Lüdemann (1998) puts it, "the phrase 'son of Mary' is so shocking that only Mark has the courage to repeat it" (55). As a result, if the New Testament is viewed as a whole, the attempt to resolve Lewin's approachavoidance conflict and put a symbolic end to paternal uncertainty is by no 
means as successful as Joseph's behavior in Matthew 1:24 appears to suggest. In fact, whether we consider Mary's premarital pregnancy in Matthew or "the son of Mary" in Mark, we see that there were nagging doubts about the sexual integrity of Jesus' mother in first-century Christianity. And these doubts must have been too well-known to hush up or else the Gospel authors would not have bothered with such embarrassing details of Jesus' genealogy. With respect to this issue in the Gospel of Luke, Jane Schaberg (1987) writes: "Luke presupposes on the part of his readership some awareness of the tradition of Jesus' illegitimacy, and he discreetly confirms this awareness" (138). The result is the persistence of paternal uncertainty as an undercurrent in the founding texts of Christian tradition.

The same can be observed from the discourse of those who have looked upon Christianity from the outside. For example, a 2nd century pagan named Celsus wrote a polemic against the fledgling religion: Jesus is cast as the product of an adulterous relationship and his mother ends up repudiated by her husband (Lüdemann, 1998: 56-7). Similarly, a Jewish medieval text entitled Toledot Yeshu proposes an account of Jesus' birth where Mary (Miriam) is engaged to a man called Yohanan while Joseph is her seducer: "At the close of a certain Sabbath, Joseph Pandera, attractive and like a warrior in appearance, having gazed lustfully upon Miriam, knocked upon the door of her room and betrayed her by pretending that he was her betrothed husband, Yohanan. [...] Lacking witnesses required for the punishment of Joseph Pandera, and Miriam being with child, Yohanan left for Babylonia" (Schaberg, 1987: 175; cf. Schlichting, 1982: 33). If the traditional story of the virgin birth mythologizes biology by saving a single mother's honor, the abandonment of Miriam by Yohanan in Toledot Yeshu reverses this process and "biologizes" mythology, i.e., the cuckolded male behaves in a biologically-grounded manner as he refuses to invest in another man's offspring.

In the secular modern view this trend has not abated by any means. In The Gospel According to Judas by the twentieth century Polish novelist Heinryk Panas, Mary conceives Jesus from her matchmaker (79) while the comic 
irreverence of Monty Python produces the following witty take on the biblical story:

Solly: What do you mean, the Holy Ghost?

Sarah: I said, the Holy Ghost done it.

Solly: He got you up the gut, the Holy Ghost did?

Sarah: Yeah.

Solly: You expect me to believe that the Holy Ghost took a night off from heaven, come down to number 42, Sheep Way, and shacked up with you? (Chapman et al., 1979: no page number).

All this indicates that the mythological attempt to symbolically wipe out paternal uncertainty has been only partially successful. The church has done its best to make the virgin birth narrative work, but the tortuous logic of the Matthew and Luke narratives clearly fails to offer a completely satisfying symbolic antidote to the age-old masculine reproductive anxiety. And so the attempt to resolve the approach-avoidance conflict by keeping Eve and Mary apart does not work: the two female symbols still represent two sides of the female condition and - most importantly - two aspects of the way this condition is perceived by the male psyche.

\section{Madonna-Whore Dichotomy}

Because the approach-avoidance conflict remains unresolved, and yet the entire Christian institution keeps insisting on the viability of Mary's impossible status, masculine anxiety is merely given a conceptual tool for the creation of a dangerously simplistic taxonomy of women. I am referring to what is known as the Madonna-Whore dichotomy in Evolutionary Psychology. To quote Lüdemann (1998), "male fantasies which style Mary a pure virgin in order to master sexual problems are unable to sublimate sexual drives in the long run. These drives discharge themselves by refunctionalizing, if not Mary herself, at least other women, as whores" (25). To be sure, this is not the invention of the Christian church but rather an evolved aspect the male psyche. Here is how the anthropologist Helen Fisher (1992) explains the origins of this 
polarization: "During our long evolutionary history [...] some women elected to be relatively faithful to a single man in order to reap a lot of benefits from him; others engaged in clandestine sex with many men to acquire resources from each. [...] Woman - the Madonna or the whore" (94; cf. Symons, 1979: 24143). However, what matters here is that, even though this anthropologist is talking about the evolution of the human mind, the Madonna image is borrowed from Christian discourse. And that discourse carries with it a conceptual framework of behavioral extremes: the Madonna represents an extreme form of sexual behavior - an impossible point of reference with immense ideological weight.

The result is that the binary opposition of female sexual strategies already present in the male psyche is made even more acute through the Christian rhetoric of polarity. Essentially, given the power of language in the cognitive process, our civilization has trapped itself linguistically - between two words: Madonna and Whore. And so women find themselves denied a taxonomic middle ground, nuance and complexity in terms of sexual behavior. To quote Robert Wright (1994), "the Madonna-whore distinction is a dichotomy imposed on a continuum. In real life, women aren't either 'fast' or 'slow'; they are promiscuous to various degrees, ranging from not at all to quite. So the question of why some women are of one type and others of the other has no meaning" (78). Well, this question certainly has meaning to many men, including Sigmund Freud (1963-1964) who uses the same biblical imagery of polarity in his famous Madonna-Whore Complex. Admittedly, in Freud's case the dynamics of the attitude toward women are somewhat different from the Madonna-Whore Dichotomy from Evolutionary Psychology, but the subtext of Christian discourse on female sexual extremes is familiar (cf. Vol. 9:173-90).

The imposition of the Madonna-Whore template on women manifests itself through numerous female opposites in literature, opera, film and other cultural manifestations. And yet again, the terminology used by critics on this subject reflects the Christian conceptual basis deriving from Marial devotion. Thus, in the case of Russian fiction, according to Rosalind Marsh (1998), "male 
writers in nineteenth-century Russia often chose to portray two contrasting types of female characters, who can be loosely interpreted in terms of the age-old opposition of Madonna and Whore. [...] Many of Dostoevsky's heroines fall into the opposing categories of the [...] respectable virgin and the sexually active woman" (10 - emphasis mine). Dostoevsky's fiction includes such Madonna-Whore pairs as Aglaia Epanchin vs. Nastassia Philippovna in The Idiot (1868-9), Dunia Raskolnikov vs. Sonia Marmeladov in Crime and Punishment $(1866)^{3}$ and numerous others. In English nineteenth century literature a prominent Madonna-Whore duo are the angelic Thomasin Yeobright and the vampish Eustacia Vye who tear Clym Yeobright's longings in two different directions in Thomas Hardy's The Return of the Native (1878). A similar opposition exists between Elizabeth and Lydia Bennet in Jane Austen's Pride and Prejudice (1813). With respect to the last example, it is interesting that the author is a woman, and yet, to quote Janet Garton (1993), "the tendency of male writing and mythology to divide women into two kinds, the 'bad' (monster, witch, whore) and the 'good' (angel, princess, Madonna) has been perpetuated by women writers such as Jane Austen and Charlotte Brontë" (116). This demonstrates the polarizing power of the Madonna-Whore dichotomy in Western cultural discourse - a notion that perpetuates itself regardless of the speaker's gender.

Nineteenth century opera was just as inclined to view women in the framework of this either-or sexual taxonomy. Thus, in Bizet's Carmen (1875), the hero Don José has to choose between the whore-like Gypsy Carmen and the chaste Madonna counterpart Micaëla. Other notable operatic Madonnas include Rossini's Anna from Maometto II (1820) and the loyal Zelmira from the eponymous 1822 opera; on the whore side perhaps the most notable example is the tragic courtesan Violetta Valéry from Verdi's La Traviata (1853). Musicologists dealing with this phenomenon also turn to the familiar Marial

${ }^{3}$ Of course Sonia Marmeladov is a complex character because she is forced into prostitution by her father's alcoholism. In fact, as many critics have pointed out, Sonia embodies the Madonna and the whore simultaneously (cf. Barsht, 2000: 35-6). 
imagery. For example, writing on Puccini's librettist Ferdinando Fontana, Iris J. Arnesen (2009) says: "Unlike Puccini, Fontana had the typical attitude of a 19th century man towards women [...] and thus both Le Villi and especially Edgar suffer terribly from madonna/whore syndrome. The heroine of Le Villi is Anna, who begins as a chaste Madonna. [...] The whore of the story is a vile courtesan $[\ldots] "(14)$.

Mid-twentieth century cinema and film critics certainly bought into Madonna-whore discourse as well. Thus, Wiliam Kerrigan (1996) talks about "what has come to be known as the 'virgin/whore' or 'Madonna/whore' split. [...] Men in classic Hollywood cinema [...] must often choose between two women, one of whom is cultured, well-bred, innocent, while the other [...] has perhaps known other men sexually. [...] Take Barbara Stanwyck in Preston Sturges's wonderful The Lady Eve" (209). Examples of this trend in cinema include Norman Jewison's The Cincinnati Kid (1965). Here the two women involved with the protagonist Eric Stoner (played by Steve McQueen) are the pure and blond Christian, whose name and hair color (traditionally indicative of purity) leave no doubt as to which pole of sexual behavior she belongs in, and the seductive, red-haired Melba. The symbolism of the latter's hair color (red for the fire of passion) and her persistent attempts to cuckold her husband Shooter by trying to seduce Stoner evoke behavior at the root of paternal uncertainty: free female sexuality and jealousy-generating extra-pair mating. The same can be said of Vincente Minelli's 1958 film Some Came Running where Dave Hirsch (played by Frank Sinatra) has to choose between the whore-like Ginnie Moorehead and the virginal Gwen French. In Richard Brooks' Elmer Gantry (1960) we find a bible-thumping evangelist Madonna called Sharon Falconer (played by Jean Simmons) preaching salvation through Christ and vying for Elmer Gantry's affections with a literal whore called Lulu Baines. 


\section{Conclusion: A Tempest in a Teapot}

Although extra-pair mating is an evolved female reproductive strategy, as is indicated by a number of the evolutionary psychologists and anthropologists cited above, the converse reproductive strategy of sexual fidelity is no less a part of the female reproductive repertoire: "During our long evolutionary history [...] some women elected to be relatively faithful to a single man in order to reap a lot of benefits from him " (Fisher, 1992: 94). And yet, Christian discourse chose to concentrate on the first strategy at the expense of the second, thereby exaggerating the impact of paternal uncertainty out of all proportion. If we recall that typically only up to about ten percent of children in most populations are not the genetic progeny of their supposed father (see Mollon, 2002, above), and if we add that Bellis at al. (2005) even argue that the ten percent figure may be overestimated (750), then we can see to what extent the creation of the Madonna symbol to counteract the genetic threat of Eve and her heirs constitutes an overreaction. Furthermore, the historical periods from which the Mary-Eve opposition originates were generally characterized by a far greater control over women's freedom of (sexual) activity than has been the case in recent times. Sexual control through domestic confinement was the norm in the Middle Ages, and even liberal thinkers saw nothing wrong with it (cf. Hastings, 1975: 52-3). For example, the preface to Giovanni Boccaccio's The Decameron (1350-3) indicates how little chance medieval women had of cuckolding their mates. The author makes it clear that his text is meant as consolation for women who are suffering from physical confinement in their households: "[The ladies] are forced to follow the whims, fancies and dictates of their fathers, mothers, brothers and husbands, so that they spend most of their time cooped up within the narrow confines of their rooms, where they sit in apparent idleness" (1972: 46; cf. Hastings, 1975: 56). Therefore, all the lusty stories of cuckoldry and sexual excess that made The Decameron so famously scandalous are in fact an attempt to compensate imaginatively for the virtual imprisonment of women in the fourteenth century. 
The creation of religious institutions and dogmatic structures in the Christian world made it possible to give inherent male anxieties ideological form which was subject to a runaway process. As the Madonna-Eve opposition gathered momentum in a self-perpetuating cycle, it turned out that the step from Marial devotion to the witch's auto-da-fé was a very easy one to make: "The veneration of the one Pure Woman, in comparison and contrast to all other Impure ones, may be helpful for celibate existence in a womanless world, [...] but for many other people the celibates have done great harm" (RankeHeinemann, 1990: 344). The Madonna-Eve opposition institutionalized by the church fathers turned the personal obsessions of a few troubled and probably sexually frustrated men into a monumental force that swept away all sense of reality and perspective, demonstrating the ability of culture to turn natural human inclinations, such as paternal uncertainty, into monsters. As the plight of women within Christendom in the past two millennia demonstrates, such monsters, once released, are very difficult to rein in.

\section{Works Cited}

Arnesen, Iris J. The Romantic World of Puccini: A New Critical Appraisal of the Operas. Jefferson, NC: McFarland and Company, 2009.

Ashe, Geoffrey. The Virgin: Mary's Cult and the Re-Emergence of the Goddess. London: Arkana: 1988.

Baker, Robin. Sperm Wars. New York: Basic Books, 2006.

Barsht, Konstantin A. "Defining the Face: Observations on Dostoevsky's Creative Process." In Eds. Catriona Kelly and Stephen Lovell. Russian Literature, Modernism and the Visual Arts. Cambridge: Cambridge University Press, 2000: 23-57.

Baumeister, Roy F. and Brad J. Bushman. Social Psychology and Human Nature. Belmont CA: Thomson, 2008.

Bellis, Mark A, Karen Hughes, Sara Hughes, John R Ashton. "Measuring Paternal Discrepancy and its Public Health Consequences." Journal of Epidemiology and Community Health 2005 (59):749-754. 
Bloch, Howard R. Medieval Misogyny and the Invention of Western Romantic Love. Chicago: The University of Chicago Press, 1991.

Boccaccio, Giovanni. The Decameron. Transl. G. H. McWilliam. London: Penguin, 1972.

Boyce, Philip Ed. Mary: The Virgin Mary in the Life and Writings of John Henry Newman. Grand Rapids, Michigan: Eerdmans, 2001.

Brown, Norman M. and Ellen S. Amatea. Love and Intimate Relationships: Journeys of the Heart. Philadelphia: Brunner and Mazel, 2000.

Buss, David. "Human Mate Guarding." Neuroendocrinology Letters 2002 (Suppl.4) 23:23-29.

Buss, David. The Dangerous Passion. New York: The Free Press, 2000.

Chapman, Graham et al. Monty Python's The Life of Brian (of Nazareth). New York: Methuen, 1979.

Coon, Dennis and John O. Mitterer. Introduction to Psychology: Gateways to Mind and Behavior. Belmont, CA: Wadsworth, 2010.

Davidson, Richard M. Flame of Yahweh: Sexuality in the Old Testament. Peabody Publishing, Massachusetts, 2009.

Dawkins, Richard. The Selfish Gene. New York: Oxford University Press, 2006.

Ebb, Fred. Chicago. 1975.

http://www.allmusicals.com/lyrics/chicago/nowadays.htm

Elliot, Andrew J. and Martin V. Covington. "Approach and Avoidance Motivation." Educational Psychology Review 13 (2) 2001: 73-92.

Fisher, Helen. Anatomy of Love: A Natural History of Mating, Marriage, and Why we Stray. New York: Random House, 1992.

Freud, Sigmund. Standard Edition of the Complete Psychological Works of Sigmund Freud. Ed. James Strachey. London: Hogarth Press, 1953-1964.

Garber, Rebecca L.R. Feminine Figurae: Representations of Gender in Religious Texts by Medieval German Women Writers 1100-1375. London: Routeledge, 2003. 
Garton, Janet. Norwegian Women's Writing, 1850-1990. London: Athlone Press, 1993.

Gerard, Harold B. and Ruben Orive. "The Dynamics of Opinion Formation." In Ed. Leonard Berkowitz Advances in Experimental Social Psychology. Vol. 20. San Diego, CA: Academic Press, 1987.

Hastings, Robert. Nature and Reason in the Decameron. Manchester: University of Manchester Press: 1975.

Hays, H.R. The Dangerous Sex: The Myth of Feminine Evil. New York: Putnams, 1964.

Holmberg, T. France: Penal Code of 1810

http://www.napoleon-

series.org/research/government/france/penalcode/c_penalcode3b.html

Karlsen, Carol F. The Devil in the Shape of a Woman: Witchcraft in Colonial New England. New York: W. W. Norton, 1987.

Lalumière, Martin L. and Kelly D. Suschinsky. "The View From the Cuckold." Evolutionary Psychology 5 (2) 2007: 358-362.

Lüdemann, Gerd. Virgin Birth? The Real Story of Mary and Her Son Jesus. Transl. John Bowden. Harrisburg, Pennsylvania: Trinity Press International, 1998.

Larner, Christina. Enemies of God: The Witch-Hung in Scotland. London: Chatto and Windus, 1981.

Kerrigan, William. "A Theory of Female Coyness." Texas Studies in Literature and Language 38.2 (Summer 1996): 209-14.

Marsh, Rosalind J. "An Image of Their Own: Feminism, Revisionism and Russian Culture." In Ed. Rosalind Marsh Women and Russian Culture: Projections and Self-Perceptions. New York: Berghahn Books, 1998: 2-41.

Miller, Ruth A. The Limits of Bodily Integrity: Abortion, Adultery and Rape Legislation in a Comparative Process. Burlington, VT: Ashgate Publishing, 2007.

Mollon, Phil. Shame and Jealousy: the Hidden Turmoils. London: Karnac Books, 2002.

Morrison, Sarah. "The Accommodating Serpent and God's Grace in Paradise Lost." Studies in English Literature 49 (Winter 2009) 1: 173-195. 
Panas, Henryk. The Gospel According to Judas. Transl. Marc E. Heine. London: Hutchinson, 1977.

Ranke-Heinemann, Ute. Eunuchs for the Kingdom of Heaven: Women, Sexuality and Catholic Church. Transl. Peter Heinegg. New York: Doubleday, 1990.

Riddley, Matt. The Red Queen: Sex and Evolution of Human Nature. New York: HarperCollins, 2003.

Riddley, Matt. The Origins of Virtue: Human Instincts and the Evolution of Cooperation. London: Penguin Books, 1996.

Schaberg, Jane. The Illegitimacy of Jesus: a Feminist Theological Interpretation of the Infancy Narratives. San Francisco: Harper and Row, 1987.

Schlichting, Günter. Ein Jüdisches Leben Jesu. Tübingen: J.C. B. Mohr, 1982.

Symons, Donald. The Evolution of Human Sexuality. New York: Oxford University Press, 1979.

Tertullian. "On the Apparel of Women." Sydney Thelwall Transl. In Alexander Roberts and James Donaldson Eds. The Ante-Nicene Fathers. Vol. 4. New York: The Christian literature publishing company, 1885-96.

Westermann, Claus. Genesis 1-11: a Continental Commentary. Minneapolos: Fortress Press, 1994.

Wohlrab-Sahr, Monika and Julika Rosenstock. "Religion - soziale Ordnung Geschlechterordnung. Zur Bedeutung der Unterscheidung von Reinheit und Unreinheit im religiösen Kontext." in Eds. Ingrid Lukatus et al. Religion und Geschlechterverhältnis. Opaden: Leske + Budrich, 2000. 279-298.

Wilson, Margo \& Martin Daly. "The Man Who Mistook His Wife for a Chattel." Eds. J.H. Barkow, L. Cosmides, J. Tooby. The Adapted Mind. Evolutionary Psychology and the Generation of Culture. New York: Oxford University Press, 1992: 289-322.

Wright, Robert. The Moral Animal: Evolutionary Psychology and Everyday Life. New York: Vintage Books, 1994. 